\title{
Comparative Study of the Treatment of Kidney Stone with Upupa Epops, Cissus Adanta Roxb and Cissus Javana DC in the Urinary Medium
}

\author{
S. O. Ibopishak, D. A. Bimola
}

\section{ABSTRACT}

\begin{abstract}
Kidney stone is a very common disease suffered by many peoples. It causes health problems such as severe pain, urinary obstruction and infection that adversely affect well being individuals. It may be treated by using allopathic and herbal drugs, lithotripsy, open surgery etc. Medicinal plants are also used for such treatment. These plants are less side effect and more economic. In this article, chemoinhibitory effects of Upupa epops, Cissus adnata Roxb and Cissus javana DC for calcium phosphate (CP) stone and calcium oxalate $(\mathrm{CaOX})$ stone formation in the aqueous and urinary media is studied. Kidney stone is treated with Hoopoe, Cissus adnata Roxb and Cissus javana DC in the urinary medium. The comparative study shows the inhibitory effect of the mixture of Hoopoe and Cissus javana DC for CP and $\mathrm{CaOX}$ stones in the aqueous and urinary media is higher and also the digestion or dissolution of kidney stone is higher by this mixture in the urinary medium.
\end{abstract}

Keywords: Allopathic drug, Herbal drug, Hoopoe, Kidney stone, Lithotripsy.

\section{INTRODUCTION}

Health is wealth. In this 21 st century, peoples are very much concerned about health. Kidney stone is one of the major health problem. It may lead to acute and renal failure. Dietary habits also help in the formation of kidney stone. Diet containing high calcium and oxalate may also enhance the formation of kidney stone i.e. CaOX [1], [2]. Patients between 30 to 50 years are suffered most.

Upupa epops known as Hoopoe(Common name) or Hudhud or Chongaraba(Local name) (Fig. 1), is a colorful bird found across Afro-Eurasia, notable for its distinctive "Crown" of feather. It is greatly extent in the family of Upapidae. The Hoopoe is the national bird of Israel (accepted in May, 2008). Upupa epops is the king of birds in Ancient Greek comedy, The Birds of Aristophanes. In Morocco, Hoopoes are traded as medicinal products in the market, primarily in the herbalists shops.

Hoopoe is used as tranquilizer. It is also used for treatment of a abdominal pain, kidney and bladder disorder. If its essence is poured in the eye, it removes the extra eyelashes and strengthens memory. It is useful in the prevention of leprosy. Its meat prevents frequent urination. Its feather is used for killing ants and fleas [3]. The blood of Hoopoe was used for eliminating fairies and nightmares and it was believed that its heart cures the diseases. Again, it is believed that its nail cure speaking disorder. It is possible that by approved of codes and fines for killing of these birds and educating by collective media, it can be protected the life of this bird.

In Old Testament, eating the meat of Hoopoe is illegal. The diet of Hoopoe includes many species considered by human to be pests, such as the pupae of the processing moth, a damaging forest pest. For this reason, the species is afforded protection under the law in many countries. Hoopoe are listed in the Deuteronomy as not kosher [4]. In olden days, the Manipuris hunted this bird species for its organ and flesh for using medicine for gall stone (stone inside the gall bladder), for the treatment of liver, kidney etc. But now-a-days the hunting of this bird is almost stopped.

Now, our main focus is the treatment of kidney stone problem. It may be treated by using allopathic drug, lithotripsy, open surgery, medicinal plants etc. Among these treatments, the use of medicinal plant is the most accepted one because these plants are less side effect and more economic. In Manipur, treatment of kidney stone problem by traditional healers(herbalists) is still going on among the meeteis, muslims, tribals [5] etc. Sri O. Nabakishor Singh (Local), a Padmashree awardee is still going on the treatment of kidney stone problems with local herbs [6]. Our present research is the treatment of kidney stone with Hoopoe, Cissus javana DC and mixture of Hoopoe and Cissus javana DC in the urinary medium. It will be one of the pioneers of this kind of study. Even though our study is against the Wild Life Conservation Law, we still practice 
this investigation for the sake of humanitarian service.

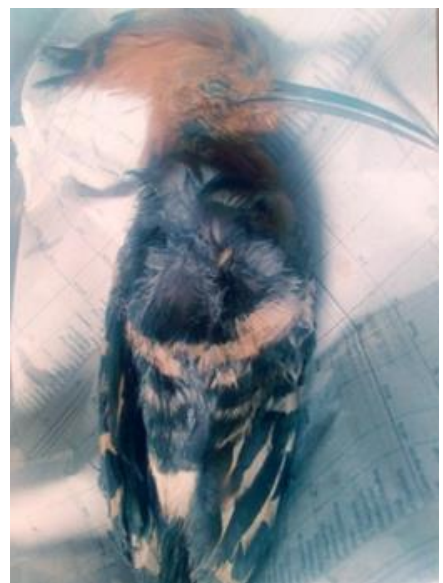

Fig. 1: Upupa epops (Hoopoe or Chongaraba).

\section{Methods AND MATERIALS}

Collection of the leaves of Cissus adnata Roxb and Cissus javana DC was done. The herbarium of the plants are already reported. The leaves were washed, dried, chopped and powdered [2], [7]. The powdered plants leaves were treated with aqueous methanol. The methanol extract was obtained with the help of Rotary Vacuum Extractor (RII) and further spread in Petridis and kept in the desiccators. At the same time, the feathers of Hoopoe, which was collected from our friend, were removed and treated with aqueous methanol $(300 \mathrm{ml})$ for 5 days. Then, it was filtered, concentrated under low temperature to get the crude mass. In the mean time kidney stones were collected from Prof. Sinam Rajen Singh, Department of Urology, Regional Institute of Medical Sciences (RIMS), Lamphel, Imphal West, Manipur. Further urine is collected from a healthy male ( 30 years), who does not have any kidney problem, kept in a container having camphor, which is used as preservative. For our experiment we always used fresh urine.

\section{A. Experimental procedure}

TABLE 1: BIRD AND MEDICINAL PLANTS WITH SCIENTIFIC AND LOCAL

\begin{tabular}{cccc}
\multicolumn{4}{c}{ NAMES AND PARTS OF BIRD AND PLANT USED } \\
\hline S1.No. & Scientific name & Local Name & Part of plant used \\
\hline 1 & Upupa epops & Chongaraba & Whole body \\
2 & Cissus adnata Roxb & Kongouyen & Leaf \\
3 & Cissus javana DC & Kongoiuyen & Leaf \\
\hline
\end{tabular}

Chemoinhibitory experiments were performed according to Rao T.V.R.K [8]. 0.01M each of $\mathrm{CaCl}_{2}$ and $\mathrm{Na}_{3} \mathrm{PO}_{4}$ were taken for $\mathrm{CP}$ crystallization. Similarly $0.01 \mathrm{M}$ each of $\mathrm{CaCl}_{2}$ and $\mathrm{Na}_{2} \mathrm{OX}$ were taken for $\mathrm{CaOX}$ crystallization. $50 \mathrm{ml}$ of plant extract (PE) and bird extract ( $0.1 \%$ of crude) in water or urine was taken as inhibitor solutions. Simultaneous blank experiments with water or urine in place of inhibitor solution were also carried out for evaluating the inhibitor efficiency of inhibitors compared to water or urine (Tables 2 and 3). All the experiments were conducted at room temperature $\left(25^{\circ} \mathrm{C}\right)$. At the end, the content of the beaker were digested on a hot water bath for 10 minutes, cooled at room temperature and centrifuged in small volume. The total centrifugates were collected. Calcium content of the centrifugate, left after stone had formed, was determined by complexometric titration using standard EDTA solution $(0,01 \mathrm{M})$, EBT $(1 \%)$ indicator and $\mathrm{NH}_{3}-\mathrm{NH}_{4} \mathrm{Cl}$ as buffer $\left(\mathrm{P}^{\mathrm{H}}-10\right)$ [9]. While calculating the $\mathrm{Ca}$ content of the centrifugate, a titre value of EDTA versus corresponding total inhibition solution was deduced from the total titre value (equivalent to centrifugate) (Table 4 to 8). Inhibition efficiency was calculating by using the following equation.

Inhibition efficiency (i.e. $\%$ Inhibition) =
$\frac{\mathrm{Ca}^{2+} \text { in centrifugate }}{\text { Total } \mathrm{Ca}^{2+} \text { inthe experiment }}$

Thus,

$\%$ increase of inhibition efficiency relative to blank $=\frac{\text { Increase of } \% \text { inhibition over blank }}{}$

$\%$ Inhibition by blank

where the total $\mathrm{Ca}^{2+}$ in the experiment equals the $\mathrm{Ca}^{2+}$ contents of $50 \mathrm{ml} \mathrm{CaCl}_{2}$ solution which was determined separately.

TABLE 2: INHIBITION EXPERIMENT FOR CP(BLANK)

\begin{tabular}{ccccccccc}
\hline & \multicolumn{3}{c}{ Water - Blank for CP } & \multicolumn{3}{c}{ Urine - Blank CP } \\
\hline Sl.No. & $\begin{array}{c}\text { IR } \\
(\mathrm{ml})\end{array}$ & $\begin{array}{c}\text { FR } \\
(\mathrm{ml})\end{array}$ & $\begin{array}{c}\text { Diff. } \\
(\mathrm{ml})\end{array}$ & $\begin{array}{c}\text { Mean } \\
(\mathrm{ml})\end{array}$ & $\begin{array}{c}\text { IR } \\
(\mathrm{ml})\end{array}$ & $\begin{array}{c}\text { FR } \\
(\mathrm{ml})\end{array}$ & $\begin{array}{c}\text { Diff. } \\
(\mathrm{ml})\end{array}$ & $\begin{array}{c}\text { Mean } \\
(\mathrm{ml})\end{array}$ \\
\hline 1 & 0 & 6.1 & 6.1 & & 0 & 10.3 & 10.3 & \\
2 & 0 & 6.0 & 6.0 & 6.0 & 0 & 10.2 & 10.2 & 10.2 \\
3 & 0 & 6.0 & 6.0 & & 0 & 10.2 & 10.2 & \\
\hline
\end{tabular}

TABLE 3: INHIBITION EXPERIMENT FOR COM(BLANK)

\begin{tabular}{|c|c|c|c|c|c|c|c|c|}
\hline \multirow[b]{2}{*}{ Sl.No. } & \multicolumn{4}{|c|}{ Water - Blank for COM } & \multicolumn{4}{|c|}{ Urine - Blank for COM } \\
\hline & $\mathrm{IR}(\mathrm{ml})$ & $\mathrm{FR}(\mathrm{ml})$ & Diff.(ml) & $\operatorname{Mean}(\mathrm{ml})$ & $\mathrm{IR}(\mathrm{ml})$ & $\mathrm{FR}(\mathrm{ml})$ & Diff.(ml) & $\operatorname{Mean}(\mathrm{ml})$ \\
\hline 1 & 0 & 1.2 & 1.2 & & 0 & 2.1 & 2.1 & \\
\hline 2 & 0 & 1.2 & 1.2 & 1.2 & 0 & 2.0 & 2.0 & 2.0 \\
\hline 3 & 0 & 1.2 & 1.2 & & 0 & 2.0 & 2.0 & \\
\hline
\end{tabular}

TABLE 4: INHIBITION EXPERIMENT FOR HOOPOE

\begin{tabular}{|c|c|c|c|c|c|c|c|c|}
\hline \multirow[b]{2}{*}{ Sl.No. } & \multicolumn{4}{|c|}{ Water $-\mathrm{BE}(0.1 \%)$ for $\mathrm{CP}$} & \multicolumn{4}{|c|}{ Urine $-\mathrm{BE}(0.1 \%)$ for $\mathrm{CP}$} \\
\hline & $\mathrm{IR}(\mathrm{ml})$ & $\mathrm{FR}(\mathrm{ml})$ & Diff.(ml) & Mean(ml) & $\mathrm{IR}(\mathrm{ml})$ & $\mathrm{FR}(\mathrm{ml})$ & Diff.(ml) & $\operatorname{Mean}(\mathrm{ml})$ \\
\hline 1 & 0 & 7.9 & 7.9 & \multirow{3}{*}{7.8} & 0 & 10.9 & 10.9 & \multirow{3}{*}{10.9} \\
\hline 2 & 0 & 7.8 & 7.8 & & 0 & 11.0 & 11.0 & \\
\hline \multirow[t]{2}{*}{3} & 0 & 7.8 & 7.8 & & 0 & 10.9 & 10.9 & \\
\hline & \multicolumn{4}{|c|}{ Water $-\mathrm{BE}(0.1 \%)$ for $\mathrm{COM}$} & \multicolumn{4}{|c|}{ Urine $-\mathrm{BE}(0.1 \%)$ for $\mathrm{COM}$} \\
\hline 1 & 0 & 1.7 & 1.7 & & 0 & 2.9 & 2.9 & \\
\hline 2 & 0 & 1.6 & 1.6 & 1.6 & 0 & 2.8 & 2.8 & 2.8 \\
\hline 3 & 0 & 1.6 & 1.6 & & 0 & 2.8 & 2.8 & \\
\hline
\end{tabular}


TABLE 5: EFFECT OF PE AND BE ON CP FORMATION IN AQUEOUS MEDIUM

\begin{tabular}{|c|c|c|c|c|c|c|c|}
\hline Sl.No. & $\begin{array}{l}\text { Bird/Plant } \\
\text { name }\end{array}$ & $\begin{array}{c}\text { Inhibitors } \\
0.1 \%\end{array}$ & $\begin{array}{c}\mathrm{Ca}^{2+} \text { in } \\
\text { solution }(\mathrm{g})\end{array}$ & $\begin{array}{c}\mathrm{Ca}^{2+} \text { in } \\
\text { precipitate(g) }\end{array}$ & $\%$ of Inhibition & $\begin{array}{c}\text { Diff. in \% of } \\
\text { inhibition } \\
\text { between sample } \\
\text { and blank } \\
\end{array}$ & $\begin{array}{c}\text { Relative } \\
\% \text { of inhibition }\end{array}$ \\
\hline 1 & $\begin{array}{l}\text { Upupa } \\
\text { epops }\end{array}$ & 7.8 & $0.0008 \times 7.8=0.00624$ & $\begin{array}{c}0.07351- \\
0.00624=0.0673\end{array}$ & $0.0624 \times 100 / 0.07351=8.4886$ & -ve & -ve \\
\hline 2 & $\begin{array}{c}\text { Upupa } \\
\text { epops }+ \\
\text { Cissus } \\
\text { adnata } \\
\text { Roxb }\end{array}$ & 7.5 & $0.0008 \times 7.5=0.0060$ & $\begin{array}{c}0.07351- \\
0.0060=0.0675\end{array}$ & $0.0060 \times 100 / 0.07351=8.1623$ & -ve & -ve \\
\hline 3 & $\begin{array}{c}\text { Upupa } \\
\text { epops }+ \\
\text { Cissus } \\
\text { javana } \text { DC }\end{array}$ & 10.5 & $0.0008 \times 10.5=0.0084$ & $\begin{array}{c}0.07351- \\
0.0084=0.0651\end{array}$ & $0.0084 \times 100 / 0.07351=11.4270$ & $\begin{array}{c}11.4270- \\
8.9240=2.5031\end{array}$ & $\begin{array}{c}2.5031 \times 100 / 8,9239 \\
=28.0494\end{array}$ \\
\hline
\end{tabular}

TABLE 6: EFFECT OF PE AND BE ON CP FORMATION IN URINARY MEDIUM

\begin{tabular}{|c|c|c|c|c|c|c|c|}
\hline $\begin{array}{l}\text { S1. } \\
\text { No. }\end{array}$ & Plant name & $\begin{array}{c}\text { Inhibitors } \\
0.1 \%\end{array}$ & $\begin{array}{c}\mathrm{Ca}^{2+} \text { in } \\
\text { solution }(\mathrm{g})\end{array}$ & $\begin{array}{c}\mathrm{Ca}^{2+} \text { in } \\
\text { precipitate }(\mathrm{g})\end{array}$ & $\%$ of Inhibition & $\begin{array}{l}\text { Diff. in \% of } \\
\text { inhibition } \\
\text { between sample } \\
\text { and blank }\end{array}$ & $\begin{array}{c}\text { Relative } \\
\% \text { of inhibition }\end{array}$ \\
\hline 1 & Uрира ерорs & 10.9 & $\begin{array}{c}0.0008 \times 10.9 \\
=0.00872\end{array}$ & $\begin{array}{c}0.07351-0.00872 \\
=0.0648\end{array}$ & $\begin{array}{c}0.00872 \times 100 / 0.07351 \\
=11.8623\end{array}$ & $\begin{array}{c}11.8623-11.1005 \\
=0.7618\end{array}$ & $\begin{array}{c}0.7618 \times 100 / 11.1005 \\
=6.8628\end{array}$ \\
\hline 2 & $\begin{array}{c}\text { Upupa epops }+ \text { Cissus } \\
\text { adnata } \text { Roxb }\end{array}$ & 13.8 & $\begin{array}{c}0.0008 \times 13.8 \\
=0.01104\end{array}$ & $\begin{array}{c}0.07351-0.01104 \\
=0.0625\end{array}$ & $\begin{array}{c}0.01104 \times 100 / 0.07351 \\
=15.0184\end{array}$ & $\begin{array}{c}15.0184-11.1005 \\
=3.9179\end{array}$ & $\begin{array}{c}3.9179 \times 100 / 11.1005 \\
=35.2948\end{array}$ \\
\hline 3 & $\begin{array}{c}\text { Upupa epops }+ \text { Cissus } \\
\text { javana } \mathrm{DC}\end{array}$ & 15.9 & $\begin{array}{c}0.0008 \times 15.9 \\
=0.01272\end{array}$ & $\begin{array}{c}0.07351-0.01272 \\
=0.0608\end{array}$ & $\begin{array}{c}0.01272 \times 100 / 0.07351 \\
=17.3038\end{array}$ & $\begin{array}{c}17.3038-11.1005 \\
=6.2033\end{array}$ & $\begin{array}{c}6.2033 \times 100 / 11.1005= \\
55.8831\end{array}$ \\
\hline
\end{tabular}

TABLE 7: EFFECT OF PE AND BE ON COM FORMATION IN AQUEOUS MEDIUM

\begin{tabular}{|c|c|c|c|c|c|c|c|}
\hline Sl.No. & Plant name & $\begin{array}{c}\text { Inhibitors } \\
0.1 \%\end{array}$ & $\begin{array}{c}\mathrm{Ca}^{2+} \text { in } \\
\text { solution }(\mathrm{g})\end{array}$ & $\begin{array}{c}\mathrm{Ca}^{2+} \text { in } \\
\text { precipitate }(\mathrm{g})\end{array}$ & $\%$ of Inhibition & $\begin{array}{c}\text { Diff. in \% of } \\
\text { inhibition between } \\
\text { sample and blank }\end{array}$ & $\begin{array}{c}\text { Relative } \\
\% \text { of inhibition }\end{array}$ \\
\hline 1 & Uрира ерорs & $\begin{array}{c}\text { Crude } \\
\mathrm{BR}=1.6\end{array}$ & $\begin{array}{c}0.0008 \times 1.6 \\
=0.00128\end{array}$ & $\begin{array}{l}0.07351-0.00128 \\
=0.07223\end{array}$ & $\begin{array}{c}0.00128 \times 100 / 0.07351 \\
=1.7413\end{array}$ & $\begin{array}{c}1.7413-1.3059 \\
=1.6651\end{array}$ & $\begin{array}{c}1.6651 \times 100 / 1.3059 \\
=127.5060\end{array}$ \\
\hline 2 & $\begin{array}{c}\text { Upupa epops }+ \\
\text { Cissus adnata } \operatorname{Roxb}\end{array}$ & $\begin{array}{c}\text { Crude } \\
\mathrm{BR}=1.3\end{array}$ & $\begin{array}{c}0.0008 \times 1.3 \\
=0.00140\end{array}$ & $\begin{array}{c}0.07351-0.00140 \\
=0.07211\end{array}$ & $\begin{array}{c}0.00140 \times 100 / 0.07351 \\
=1.9045\end{array}$ & $\begin{array}{l}1.9045-1.3059 \\
=1.3060\end{array}$ & $\begin{array}{c}1.3060 \times 100 / 1.3059 \\
=100.0077\end{array}$ \\
\hline 3 & $\begin{array}{c}\text { Upupa epops }+ \\
\text { Cissus javana DC }\end{array}$ & $\begin{array}{c}\text { Crude } \\
\mathrm{BR}=1.2\end{array}$ & $\begin{array}{c}0.0008 \times 1.2 \\
=0.00096\end{array}$ & $\begin{array}{c}0.07351-0.00096 \\
=0.07255\end{array}$ & $\begin{array}{c}0.00096 \times 100 / 0.07351 \\
=1.3059\end{array}$ & $\begin{array}{c}1.3059-1.3059 \\
=0\end{array}$ & 0 \\
\hline
\end{tabular}

TABLE 8: EFFECT OF PE AND BE ON COM FORMATION IN URINARY MEDIUM

\begin{tabular}{|c|c|c|c|c|c|c|c|}
\hline S1.No. & Plant name & $\begin{array}{c}\text { Inhibitors } \\
0.1 \%\end{array}$ & $\begin{array}{c}\mathrm{Ca}^{2+} \text { in } \\
\text { solution }(\mathrm{g})\end{array}$ & $\begin{array}{c}\mathrm{Ca}^{2+} \text { in } \\
\text { precipitate }(\mathrm{g})\end{array}$ & $\%$ of Inhibition & $\begin{array}{c}\text { Diff. in \% of } \\
\text { inhibition between } \\
\text { sample and blank }\end{array}$ & $\begin{array}{l}\text { Relative } \% \text { of } \\
\text { inhibition }\end{array}$ \\
\hline 1 & Uрира ерорs & $\begin{array}{c}\text { Crude } \\
\mathrm{BR}=2.8\end{array}$ & $\begin{array}{c}0.0008 \times 2.8 \\
=0.00224\end{array}$ & $\begin{array}{c}0.07351-0.00224 \\
=0.0713\end{array}$ & $\begin{array}{c}0.00224 \times 100 / .07351 \\
=3.0472\end{array}$ & $\begin{array}{l}3.0472-2.7207 \\
\quad=0.3265\end{array}$ & $\begin{array}{c}0.3265 \times 100 / 2.7207 \\
=12.0006\end{array}$ \\
\hline 2 & $\begin{array}{c}\text { Upupa epops }+ \text { Cissus } \\
\text { adnata } \operatorname{Roxb}\end{array}$ & $\begin{array}{c}\text { Crude } \\
\mathrm{BR}=4.5\end{array}$ & $\begin{array}{l}0.0008 \times 4.5 \\
=0.0036\end{array}$ & $\begin{array}{c}0.07351-0.0036 \\
=0.0699\end{array}$ & $\begin{array}{c}0.0036 \times 100 / 0.07351 \\
=4.8973\end{array}$ & 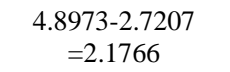 & $\begin{array}{c}2.1766 \times 100 / 2.7207 \\
=80.0015\end{array}$ \\
\hline 3 & $\begin{array}{c}\text { Upupa epops }+ \text { Cissus } \\
\text { javana } \mathrm{DC}\end{array}$ & $\begin{array}{c}\text { Crude } \\
\mathrm{BR}=7.5\end{array}$ & $\begin{array}{c}0.0008 \times 7.5 \\
=0.0060\end{array}$ & $\begin{array}{c}0.07351-0.0060 \\
=0.0675\end{array}$ & $\begin{array}{c}0.0060 \times 100 / 0.07351 \\
=8.1622\end{array}$ & $\begin{array}{c}8.1622-2.7207 \\
=5.4415\end{array}$ & $\begin{array}{c}5.4415 \times 100 / 2.7207 \\
=200.0037\end{array}$ \\
\hline
\end{tabular}

\section{RESUlTS AND DISCUSSION}

From the above experimental findings, the effectiveness of the relative percentage (p.c) of inhibition against $\mathrm{CP}$ formation in aqueous medium is nil while that of Upupa epops and Cissus javana DC is found to be 28-.0494 (Table $5)$. But in the urinary medium, the relative p.c of inhibition of the mixture of Upupa epops and Cissus javana DC is the highest i.e. 55.8831 (Table 6)

In the case of COM, the relative p.c of inhibition of the mixture Upupa epops and Cissus adnata Roxb in the aqueous medium is the highest.e. 100.0077 (Table 7). While in the urinary medium the highest relative p.c of inhibition for COM formation is shown by Upupa epops and Cissus javana DC and its value is 200.0037 (Table 8).

Hence, there is less inhibitory effect of Hoopoe and mixture of Hoopoe and Cissus adnata Roxb except the mixture of Hoopoe and Cissus javana DC which has the higher inhibitory against the $\mathrm{CP}$ stone formation both in aqueous and urinary media. Further the inhibitory effect of mixture of Hoopoe and Cissus javana DC for COM stone formation in the aqueous medium is nil while it has the highest inhibitory effect for COM stone formation in the urinary medium. That is why our traditional healers practiced this activity for the treatment of kidney stone patients.

Further in vitro, We took Hoopoe (Chongaraba) and Cissus javana DC (Kongouyen laba) and were treated with kidney stone(collected) in the urinary medium. The experimental observations are shown in Table 9. 


\begin{tabular}{|c|c|c|c|c|c|c|c|c|}
\hline $\begin{array}{c}\text { S1.No } \\
.\end{array}$ & Medium & Extracts & $\begin{array}{l}\% \text { of } \\
\text { Crude }\end{array}$ & Dura -tion & $\begin{array}{l}\text { Mass of kidney } \\
\text { stone before } \\
\text { treatment with } \\
\text { extracts }(\mathrm{g})\end{array}$ & $\begin{array}{l}\text { Mass of kidney } \\
\text { stone after } \\
\text { treatment with } \\
\text { extracts }(\mathrm{g})\end{array}$ & $\begin{array}{l}\text { Difference } \\
\text { mass of } \\
\text { kidney stone } \\
(\mathrm{g})\end{array}$ & $\begin{array}{l}\text { Rate of Digestion/ } \\
\text { dissolution of Kidney } \\
\text { stone per hour }\end{array}$ \\
\hline 1 & Urine & Upupa epops & 0.1 & 4 hours & 0.0670 & 0.0670 & 0 & 0 \\
\hline 2 & Urine & $\begin{array}{c}\text { Cissus } \\
\text { Javana DC }\end{array}$ & 0.1 & 4 hours & 0.8490 & 0.8442 & 0.0048 & $1.200 \mathrm{mg}$ \\
\hline 3 & Urine & $\begin{array}{c}\text { Upupa epops } \\
+ \text { Cissus } \\
\text { javana DC }\end{array}$ & 0.1 & 4 hours & 0.6330 & 0.6261 & 0.0069 & $1.725 \mathrm{mg}$ \\
\hline
\end{tabular}

From the experimental results, Hoopoe alone has no effect in the digestion of kidney stone in the urinary medium. The digestion of kidney stone by Cissus javana DC is found to be $0.025 \mathrm{mg}$ per hour while that of the mixture of Upupa epops and Cissus javana DC is $0.050 \mathrm{mg}$ per hour. Therefore, it is noticed that the digestion/dissolution of kidney stone is the highest in the mixture of Hoopoe and Cissus javana DC. Cissus javana DC alone can digest or dissolve kidney stone and its activity is enhanced when mixed with Hoopoe. This concept is utilized by our traditional healers.

\section{ACKNOWLEDGMENT}

The authors express their gratitude to the UGC, New Delhi for the financial assistance. The authors also extent their thankfulness to the Principal Chief Wild Life Warden (PCCF), Government of Manipur, for granting permission to undergo research work with Hoopoe in connection with the publication of this article.

\section{REFERENCES}

[1] Marica Y.M.F., Kaivisweswaran R(1994). "Stone disease In: Essential of Nephrology and Urology", New Delhi, India: Churchil Livingstone Pvt Ltd

[2] Bimola Devi Asem, Warjeet Singh Laitonjam, Ibopishak Singh Oianam, Jeena Devi Thangjam(2012), "Studies of the Chemiinhibitory Effects of Aqueous Extract of Cissus adnata Roxb and its isolated Compounds on Urinary Lithiasisnin vitro conditios", Int Journal Pharmaceutical Research, 4(4):1-4.

[3] Kamran Pashayi Fakhri, Rogayye Mahmoodivand, Bakhtiari, Parvaneh Adelzadeh(June 2014), "Hoopoe in Persian Literature and Myths", Int Archive of Applied Science and Technology, 5(2):41-44.

[4] Deuteronomy chaper14, pp18, mechon- mamre.org.

[5] Mohd Mustaque A, Kumar Singh P(2011), "Traditional knowledge of Kidney Stones Treatment by Muslim Maiba(Herbalists) of Manipur", Notulae Scientia biologicae, 3(2):12-15.

[6] Ibopishak Singh Oinam, Bimola Devi Asem(2016)," Comparative Study of the Antiurolithiatic Activity of Plant Hydroalcoholic Extract of Argemone Mexicana, Cissusjavana Roxb and Garcinia marginatum", Int Journal of Science and Research, 5(5):2066-70.

[7] Gayatri R and Manju L(Jan 2020),"Identification and comparative study of in vitro Antioxidant potential of fractionated hydroalcoholic extract of Phyllanthus niruri Linn", ejchem, 1(1):1-4.

[8] T.V.R.K. Rao and V.K. Choudhury(2008), "Chemoinhibition of Mineralization of Urinary Stone forming minerals by some Inorganic and Organic salts of Aluminium in Aqueous and Urinary Media", Asian Journal of Chemistry, 20(7):5046-5052.

[9] A.I.Vogel (1978), "Text Book of Quantitative Inorganic Analysis", edn 4, London, ELBS, and Longman.

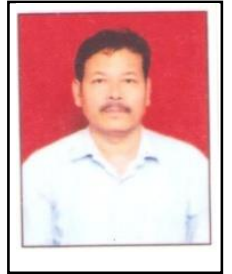

Ibopishak S. O. Associate Professor, Chemistry Department, Modern College (affiliated to MU, Canchipur), Imphal East - 795005, Manipur, India. $\mathrm{He}$ is an Associate Professor of Chemistry Departmnet, Modern College (Degree College) and has a teaching experience of 30 years. He got his $\mathrm{PhD}$ degree from Chemistry Dept. Manipur University, Canchipur in thje year 2003. He has national and International published papers. He has two M Phil students. His main field of research is synthesis of Inorganic complexes and medicinal plants

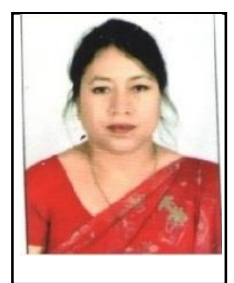

Bimola D. A. Associate Professor, Chemistry Department, Modern College(affiliated to MU, Canchipur).

She is an Associate Proffessor of Biochemistry, Modern College. She was awarded $\mathrm{PhD}$ degree from Chemistry Dept. Manipur university, Cachipur. She is guiding graduate students with 27 years teaching experience. She possesses national and International published papers. She has 1 year teaching experience of PG students of DM University, Manipur, India. She got the best paper presenter in the Refresher course organized by Chemistry Department, Gauhati University, Assam, India. She studies mainly treatment of diseases with local medicinal plants. 